describe it as being nearly as large as the full moon and greatly exceeding it in brilliancy. An observer at Ashbyde-la-Zouch first noticed his shadow, and those of neighbouring trees thrown tozerards the moon, then shining brilliantly in the east. Persons much nearer the scene, sitting in rooms with the blinds down, were frightened by the flood of light that suddenly found its way in. The meteor exploded with great violence at the height of I4 miles over the Irish Sea, 20 miles N.N.W. (true) of Llandudno. The total length of path was 135 miles, which was traversed in about 8 seconds of time, or with a velocity of $17 \frac{1}{2}$ miles per second, as determined from twenty-three estimations of its duration.

The streak left in the air extended for 40 miles along the track, and was not less than 2,000 feet in diameter.

The violence of the explosion was such, that at Bangor, Beaumaris, Conway, and Llandudno, doors and windows rattled, and people ran out to see what was the matter. As far as Chester the sound resembled "thunder not very far distant," or " a salvo of artillery."

It is a fact worthy of thoughtful consideration that the body which was capable of producing this convulsion, probably exceeding the discharge of the 81 -ton gun in the proportion of a hundred to one, was converted into impalpable powder in eight seconds of time, merely by the rapidity of its transmission through very attenuated air. After the explosion nothing remained but dully incandescent dust or ashes, which slowly fell a short distance vertically downwards. That is to say, there was not one remnant sufficiently heavy to continue in the same direction, or to retain the original velocity, because such a remnant would have been visible itself as a bright meteor. A momentum which, estimated in foot-tons, would reach some enormous figure, was instantaneously reduced to nothing, or, rather, converted into atmospheric waves-and dust !

The exact position and height of the explosion is fixed by the singular observation of Mr. Petty, at Llandudno (NATURE, vol. xvii. p. 183), who did not even see the meteor itself, but its light on the hearthrug coming through a chink in the blind.

Mr. J. Ismay, the superintendent of telegraphs at Liverpool, who observed the explosion from the beach at Llandudno, measured the sound-interval, and found it between 2 min. and $2 \mathrm{~min}$. 15 secs. From the spot where I have assumed the explosion took place to bis position is 25 miles, which sound would traverse in two minutes exacrly.

The orbit deduced from the apparent position of the radiant point is-

$$
\begin{gathered}
i=0 \\
\pi=153^{\circ} \\
q=47 \\
\text { Motion direct. }
\end{gathered}
$$

The relative velocity obtained by assuming a parabolic orbit is 19 miles per second, agreeing very closely with that found by observation.

If the longitude of the radiant be diminished $3^{\circ}$ or $4^{\circ}$, the orbit is so far modified as to almost coincide with that of the comet of 1702 . The comet was not very well observed. The meteor belonged to the wellknown shower of Taurids, first discovered by Mr. R. P. Greg, encountered by the earth with great regularity about November $21-23$. In 1877 it appears to have been very prolific of bright and of detonating meteors.

\section{G. L. TUPMAN}

\section{OUR ASTRONOMICAL COLUMN}

THE COMETS OF I6I8.- The year 16 I8 presented a phenomenon which is perhaps unique in the history of the appearances of comets, two of these bodies having been conspicuously visible at the same time in certain parts of he earth, and for several days, at least, in the same quarter of the heavens, with trains of thirty or forty degrees in length, and upwards. Cometographers previous to Pingré had been much exercised with reference to the comets of this year; Comiers, in "I.a Nature et Prestige des Cometes," had supposed that six comets in all were observed in 1618 ; this number was reduced by Pingré to three, which appears to have been beyond doubt the correct number, though another cometographer, Struyck, disputed the distinctness of Pingrés second.

The first comet was discovered at Caschau, in Hungary, on August 25, and two days later by Kepler, at Lintz, where it rose in the morning about three o'clock, with a tail directed towards the west. Kepler observed it on several occasions, and for the last time on the morning of September 25, and from his rough indications of its positions Pingré calculated the elements which figure in our catalogues, and which it will be found represent the track of the comet pretty nearly ; there can be no confusion between this object and the second or third comets of the year.

The third comet, as Pingré remarks, " eut autant d'observateurs qu'il y avoit alors d'astronomes en Europe." It was first seen in Europe in the last days of November, and was observed by Cysat at Ingoldstat till January 2I, he having used optical aid, though other observers lost it at the beginning of the month, or even earlier. The elements, first calculated by Halley, were more accurately investigated by Besse], whose orbit, published in 1805 , agrees with the observations as closely as the errors, with which they are obviously affected, will allow. There is no difficulty, therefore, in fixing upon the position of the third comet, with sufficient approximation in the month of November previous to its discovery in Europe.

It appears to have been one of the finest comets of the seventeenth century, apparently hardly exceeded in the imposing character of its appearance by the celebrate comet of 1680 . The tail gradually increased in length until, on the morning of December ro, the Danish astronomer, Longomontanus, estimated its extent at $104^{\circ}$, with marked coruscations.

The second comet of 1618 , according to Pingré, to which these remarks are intended more particularly to refer, was discovered in Silesia, and also at Rome, on the morning of November II, as Kepler tells us (De Cometis lib. I.). The nucleus was lost in the twilight, but the tail was visible from $4 \mathrm{~h}$. 20m. to 6 h. $40 \mathrm{~m}$. at Kome. On the following mornings the tail was seen at other places in Europe, and by Kepler himself at Lintz, at 5h. 30m. A.M. on November 20 ; he then describes it as a train of milkywhite light, passing below the stars in the quadrilateral of Corvus, and reaching the extremity of Crater. He saw this train for the last time on the morning of November 29 , when "inter atras nubes et ventos vehementes, cum campi essent picti nivula, apparuit tamen tractus iste secundi cometæ, sed valde dilutus nec æquans albedinem nubium a luna illuminatarum." This was at 5 A.M., and an hour and a half later, the clouds having somewhat dispersed, he obtained his first view of the third comet, which was then in Iongitude $221^{\circ}$, with between $9^{\circ}$ and $10^{\circ}$ north latitude. Thus we see that Kepler saw both comets on the same morning, though he failed to detect the nucleus of the second in the strong twilight; and it may be added that Blancanus, at Parma, had similar experience.

In more southern latitudes the second comet was pretty favourably situated for observation, and its nucleus was observed. Figueroes, ambassador of Spain, at Ispaban, and the Jesuits at Goa, saw both comets simultaneously, and determined positions of the nucleus of the second. Riccioli mentions that Father Kirwitzer, an Austrian, was sent out to China, and died at Macao in 1626, adding that he wrote of observations made in India on the comets of 1618 . 
In a communication to Baron de Zach early in 1821 , Olbers states that Brandes had sent him a work by this Father Kirwitzer, which it appeared had become very scarce, containing observations of the second comet of 1618 , but so disfigured by faults either in copying or printing, that he had found it impossible to deduce from them a tolerable orbit. According to these observations "la comète sautiile d'un jour à l'autre ça et là dạns le ciel; tantôt en avant, tantôt en arrière, de sorte qu'à peine peut-on reconnaître quelle a été la vraie direction de son mouvement." Kirwitzer, who had observed the comet from November 14, reports that on November 26 he was joined in the observations by Father Schall, and Olbers drew attention to the fact that in Zach's Monatliche Correspondenz, vol. xxviii., it had been stated that fourteen volumes of Schall's manuscripts were in existence in the library of the Vatican, and engaged Zach to use his interest towards having them examined. This was soon after effected by Conti, but unfortunately no allusion to the second comet of 1618 was found in them, indeed these manuscripts proved so worthless, that $Z$ ach considered them "que de la poudre chinoise jeté aux yeux européens." It does not appear that a more accurate copy of the Goa observations has been found since Olbers wrote on the subject. There are two works by Kirwitzer in the British Museum, but they afford no assistance. It thus happens that there is as yet no orbit of the comet in question.

In a further note we shall briefly recapitulate other circumstances in the history of the comet, and examine one or two points in which the known elements of the third comet assist in establishing the absolute distinctness of the second, notwithstanding the idea advocated by Kepler that a comet had divided into two-and which led Pingré to say of him-aliquando bonus dormitat Homerus.

\section{METEOROLOGICAL NOTES}

Contribution to the Climatology of the SPANISH PENINSUL.A.-An interesting and able contribution to the climatology of the Spanish Peninsula has been made by Dr. Hellmann in a discussion of the humidity and clouds of that region, published in the Dutch Meteorological Year-Book for I876, being one of the results of the author's recent prolonged meteorological tour in the Peninsula. One of the broad results arrived at is this: the small variation in the annual humidity of places on the west coasts of Europe, as contrasted with the large variation in the humidity of the east coasts of Asia, together with the striking climatic contrasts resulting therefrom is essentially, though less intensely, reproduced in the climates of the Peninsula of the west bordering the Atlantic as contrasted with those of the east washed by the Mediterranean. As regards the relative humidity of the air, the climate is moister in May than it is immediately before and after, and it is interesting to observe that thunderstorms, rain, and cumulus, cirro-cumulus, and cumulo-stratus clouds show an increase in May as compared with March and April on the orie hand, and June and July on the other. The annual variation in the relative humidity increases from about four to nine per cent. on the coasts, to about forty per cent. at such inland places as Madrid and Campo Maio. Those who are familiar with the weather-maps of Europe are aware how often atmospheric pressure is so distributed as to give rise to winds blowing outwards from the Peninsula to the ocean in all directions, being easterly on the west coast, southerly on the north, westerly on the east, and northerly on the south. They are everywhere dry winds, and are known in the various provinces as the Terral, or landwind. The desert-wind of the Spanish Mediterranean coast is the Leveche, and not the Solano, as it is almost uni- versally stated to be by non-Spanish writers. The Solano is, as its name implies, a simple east wind which blows everywhere over the east coasts, and is a rain-bringing wind, but in no sense a desert-wind, malignant and prostrating in its effects. The true desert-wind is known by the name of the Leveche, which is usually loaded with fine sand and dust, and is hot and stifling, is productive of violent headaches, and prostrates even the most robust with a feeling as if every member of the body were oppressed under a load of lead. Dr. Hellmann describes the effects of the passage of one over a vineyard in August 1876 , the appearance being as if a scorching flame had passed over it. The Leveche is felt on the coast only from Cabo de $\mathrm{NaO}$, to $\mathrm{Cab}$ de Gata in the south, and in a less severe form as far as Malaga ; but it extends inland no farther than from forty to fifty miles.

Climatology of the Fije Islands.-A valuable contribution to this subject from data collected by the Meteorological Office has appeared in the Quarterly Fournal of the Meteorological Society for July, 1877. From the position of the Fiji Islands in the South Pacific, the climate is strictly tropical, the year being divided into a hot moist season, extending from November to April, and a cool dry season from May to October. The prevailing winds are S.E. and E., but during the hot season, particularly from January to March, N.E. winds prevail. These N.E. winds are, in Mr. Strachan's opinion, probably due to the heated land of the large island, Viti Levu, giving rise to a wind of aspiration. The annual rainfall on an average of six years was 1 ro inches. The heaviest falls occur in the summer months of January, February, and March, when thunderstorms are frequent, and in the same months hurricanes occur, though frequently several years pass in succession without the occurrence of any hurricane. In the cool season the rainfall, though considerable, is reduced in amount and frequency, and in all seasons there is a considerable difference as regards moisture and rainfall between the wind ward and lee sides of the different islands, the effect being strikingly shown by the difference of vegetation. The working out of this question of the distribution of the rainfall by such a multiplication of gauges over the islands as has been so successfully done in the Mauritius and Barbadoes, is most desirable from the scientific and practical importance of the subject. The mean annual temperature is about $77^{\circ} \cdot 5$, and the difference between the hottest and the coldest months scarcely reaches $5^{\circ}$. In the wet season atmospheric pressure is about 29.870 inches, and vapour tension 0.860 incb, but in the dry season 30020 inches, and 0700 inch, thus showing considerable variation through the year in the pressure and vapour tension of a climate characterised by comparatively so little variation as that of $\mathrm{Fiji}$.

Extension of Volunteer Weather Service iN THE UNITED STATES.-We are greatly gratified to see that the marked success which has attended the volunteer weather service in the State of Iowa, so vigorously prosecuted by Dr. Hinrichs, and which now numbers about 100 observers, is leading other states to adopt a similar system. Prof. Francis E. Nipher, of the Washington University of St. Louis, has already secured the services of fifty-five observers, chiefly in the northern and western parts of Missouri, for the regular observations, particularly of rainfall, but also, where possible, of temperature pressure and humidity ; and for observations of irregularly recurring phenomena, such as storms, the aim being to collect together as full and accurate an account of the different phases of these phenomena as it is possible to make, particularly their commencernent, culmination, and termination. The investigation of the climatology of the state is also to be undertaken. The observations are to be according to local time. Regular reports will be furnished to the newspaper press. The work is under- 